\title{
ANALISIS FAKTOR-FAKTOR PENYEBAB KEENGGANAN MASYARAKAT MEMBAYAR ZAKAT MELALUI BAZNAS KABUPATEN KUANTAN SINGINGI
}

\author{
Meri Yuliani ${ }^{1}$, Dian Meliza ${ }^{2}$, \& Fitrianto $^{3}$ \\ Fakultas Ilmu Sosial, Universitas Islam Kuantan Singingi (UNIKS) \\ E-mail:meriyuliani6@gmail.com,dianhabibi2011@gmail.com,fitri197uniks@gmail.com
}

\begin{abstract}
ABSTRAK
Tujuan dari penelitian ini adalah untuk mengetahui tentang sistem pengumpulan zakat oleh BAZNAS Kabupaten Kuantan Singingi, analisis faktor-faktor penyebab keengganan masyarakat dalam membayar zakat melalui BAZNAS Kabupaten Kuantan Singingi dan untuk mengetahui kebijakan yang ditempuh oleh BAZNAS Kabupaten Kuantan Singingi dalam menarik masyarakat (Non PNS) untuk membayar zakatnya melalui BAZNAS. Penelitian ini merupakan penelitian lapangan (Field Research) dengan teknik analisa data yang digunakan adalah deskriftif kualitatif. Dari hasil penelitian dapat disimpulkan bahwa sistem pengumpulan zakat oleh BAZNAS Kabupaten Kuantan Singingi menggunakan 2 (dua) sistem yaitu pertama, zakat lansung dijemput oleh pihak BAZNAS kepada muzakki dan kedua, muzakki menyetor lansung zakatnya ke BAZNAS Kuantan Singingi. Sedangkan faktor-faktor yang menyebabkan keengganan masyarakat untuk membayar zakat melalui BAZNAS Kuansing adalah Masyarakat ingin bayar sendiri zakatnya kepada mustahiq yang di kehendakinya dan juga disebabkan kurangnya tingkat kepercayaan masyarakat tersebut kepada BAZNAS, kemudian juga disebabkan muzakki kurang mengerti bagaimana prosedur ataupun cara pembayaran zakat melalui BAZNAS Kabupaten Kuantan Singingi. Kebijakan yang dilakukan oleh BAZNAS Kabupaten Kuantan Singingi dalam menarik muzakki atau masyarakat untuk membayar zakatnya melalui BAZNAS dengan gencar mensosialisasikan keberadaan BAZNAS itu sendiri kepada masyarakat.
\end{abstract}

\section{Kata Kunci :Keengganan, Masyarakat, Zakat, BAZNAS.}

\begin{abstract}
The purpose of this study was to find out about the zakat collection system by BAZNAS in Kuantan Singingi Regency, analysis of factors that caused people's reluctance to pay zakat through BAZNAS in Kuantan Singingi Regency and to find out the policies pursued by BAZNAS in Kuntan Singingi Regency in attracting people (Non PNS) to pay zakat through BAZNAS. This research is a field research with the data analysis technique used is descriptive qualitative. From the results of the study it can be concluded that the zakat collection system by BAZNAS in Kuantan Singingi Regency uses two systems, namely first, the zakat is directly picked up by the BAZNAS to the muzakki and secondly, muzakki deposits the zakat directly to the BAZNAS in Kuantan Singingi Regency. Whereas the factors that cause people's reluctance to pay zakat through BAZNAS Kuantan Singingi Regency are the people who want to pay their own zakat to mustahiq which they want and also due to the lack of trust in BAZNAS, and also because muzakki doesn't understand the procedure or how to pay zakat through BAZNAS in Kuantan Singingi Regency. The policy carried out by BAZNAS Kuantan Singingi Regency in attracting muzakki or the community to pay their zakat through BAZNAS by intensively socializing the existence of BAZNAS itself to the community,
\end{abstract}

Keywords: Reluctance, Society, Zakat, BAZNAS. 
PENDAHULUAN

Islam mengajarkan beberapa cara yang dapat dilakukan dalam menangani masalah kemiskinan,yakni dengan saling tolong-menolong antar manusia melalui sedekah maupun zakat. Menunaikan zakat merupakan salah satu rukun Islam yang wajib dilaksanakan setiap muslim. Konsep zakat dalam Islam menyatakan, terdapat sebagian hak bagi orang lain terutama hak kaum fakir miskin terhadap orang-orang yang memiliki harta berlebih. Harta yang dimiliki akan lebih berkah jika sebagian dari harta itu dapat disalurkan baik dengan sedekah maupun zakat. Hal ini tentu sedikit banyak akan sangat membantu dalam pengentasan kemiskinan.

Pada dasarnya zakat dikenakan pada harta yang diperoleh dan dimiliki oleh seorang muslim. (Mursyidi, 2003). Zakat sebagai ibadah maliyah (harta benda) pelaksanaannya tidak sekedar suka rela namun merupakan suatu kewajiban individu muslim. Dalam perspektif al-Qur'an, zakat begitu strategis, ini terlihat dari banyaknya ayat dalam al-Qur'an yang menyandingkan perintah zakat dengan perintah shalat sebanyak 32 ayat.

Peran pemerintah sangat strategis dalam mendorong keberhasilan pengelolaan zakat di Indonesia. Dukungan dan peran pemerintah akan berdampak positif bagi kehidupan bernegara secara menyeluruh. Merupakan hal yang wajar apabila pemerintah yang berkuasa melakukan tindakan berdasarkan kewenangan dan kekuasaan yang dimilikinya guna memihak pada rakyatnya. Oleh karena sebagian besar masyarakat muslim adalah miskin, maka pemerintah wajib bertanggung jawab untuk memberikan solusi terhadap beban kemiskinan rakyatnya. Karena zakat merupakan pranata keagamaan yang bertujuan untuk meningkatkan keadilan dan kesejahteraan masyarakat. (UndangUndang No. 23 Tentang Pengelolaan Zakat, 2011)

Dalam ajaran inti agama Islam sebetulnya telah mengenal organisasi manajemen pengelolaan zakat sebagaimana ditunjukkan dalam al Qur'an surat At Taubah ayat 60 :

"Sesungguhnya zakat-zakat itu, hanyalah untuk orang-orang fakir, orang-orang miskin, pengurus-pengurus zakat, para mualaf yang dibujuk hatinya,untuk (memerdekakan) budak, orang-orang yang berhutang, untuk jalan Allah, dan orangorang yang sedang dalam perjalanan, sebagai sesuatu ketetapan yang diwajibkan Allah, dan Allah Maha Mengetahui lagi Maha Bijaksana”.

BAZNAS adalah lembaga pengelola zakat yang melakukan pengelolaan secara nasional. Sistem pengelolaan zakat terdapat dalam Undang-Undang No. 38 Tahun 1999 di dalamnya mengatur tentang pelaksanaan pengelolaan zakat mulai dari perencanaan sampai pada tahap pendistribusian dan pendayagunaannya. (Hasan, 2006)

Di Kabupaten Kuantan Singingi telah dibentuk Badan Amil Zakat Nasional (BAZNAS) yang merupakan induk dari semua Badan Amil Zakat yang ada di Kabupaten Kuantan Singingi yang mulai beroperasi pada tahun 2007 . Badan Amil Zakat ini berlokasi di jl. Jendral Sudirman No. 98 Teluk Kuantan yang kegiatan utamanya adalah mengumpulkan, mendistribusikan dan mendayagunakan zakat sesuai dengan ajaran Islam.

Tugas dalam pengelolaan zakat tersebut diantaranya adalah meningkatkan kesadaran masyarakat dalam menunaikan zakat kepada BAZNAS Kabupaten Kuantan Singingi dengan melakukan sosialisasi kepada masyarakat dan mengirim himbauan penunaian zakat ke setiap dinas-dinas 
dan instansi/swasta dalam perwujudan ketaatan terhadap Hukum Allah SWT.

Berdasarkan dari hasil wawancara dengan Nafizah (Staf Sekretariat BAZNAS) mengatakan bahwa zakat yang terkumpul di BAZNAS Kabupaten Kuantan Singingi banyak terkumpul hanya dari Unit Pengumpul Zakat (UPZ) melalui dinasdinas dan instansi/swasta, sedangkan masyarakat secara umum hanya sedikit sekali yang menyetorkan zakatnya melalui BAZNAS Kabupaten Kuantan Singingi (Nafizah, Sekretariat BAZNAS Kabupaten Kuantan Singingi, Wawancara, Teluk Kuantan, 7 Desember 2016)

Masyarakat yang berada di Kabupaten Kuantan Singingi ini mayoritas beragama Islam, berdasarkan data yang penulis dapatkan jumlah masyarakat muslim di Kabupaten Kuantan Singingi berjumlah 324.158 orang, (BIMAS Islam Kementrian Agama Kabupaten Kuantan Singingi tahun 2015). Sedangkan masyarakat yang diluar Pegawai Negeri Sipil (PNS) hanya sebagian kecil saja yang membayar zakatnya melalui BAZNAS Kabupaten Kuantan Singingi ini yaitu pada tahun 2016 hanya 4.106 orang muzakki. (Laporan BAZNAS Kabupaten Kuantan Singingi Tahun 2016)

Realita yang ada menjadi suatu persoalan yang perlu kajian secara komprehensif untuk melihat faktorfaktor penyebab keengganan masyarakat (Non PNS) membayar zakat melalui BAZNAS Kabupaten Kuantan Singingi yang seharusnya penerimaan zakatnya tidak hanya banyak dari dinas-dinas dan instansi/swasta tetapi juga dari masyarakat yang bukan Pegawai Negeri Sipil (PNS), karena umumnya masyarakat yang ada di Kabupaten Kuantan Singingi ini beragama Islam.

\section{TINJAUAN PUSTAKA} Pengertian Zakat

Zakat adalah salah satu unsur dari rukun Islam. Ia ditempatkan pada unsur yang ketiga atau yang paling tengah. Ia merupakan satu-satunya unsur rukun Islam yang langsung berkenaan dengan perekonomian umat Islam. (Halim, 2001). Zakat bertujuan untuk mengatasi kesenjangan sosial antara si kaya dengan si miskin. Selain itu, zakat juga dapat mempererat hubungan antara manusia dengan sang pencipta.

Secara bahasa (etimologi) zakat berarti suci, tumbuh, berkembang, penuh keberkahan, serta beres harta, jiwa, dan prilaku. (Hafidhuddin, 2003) Zakat, berarti suci, tumbuh, bertambah, dan berkah. Dengan demikian, zakat itu membersihkan (menyucikan) diri seseorang dan hartanya, pahala bertambah, harta tumbuh (berkembang), dan membawa berkat. Menurut istilah (terminologi) zakat adalah, kadar harta tertentu yang diberikan kepada yang berhak menerimanya, dengan syarat tertentu. (Hasan, 2003) Sedangkan menurut pengertian hukum syara' adalah Jumlah dari harta tertentu yang harus dikeluarkan (di zakatkan) oleh yang wajib zakat kepada yang berhak menerimanya menurut hukum syara'. (Effendy, 1996) Sedangkan zakat dari istilah fiqih berarti sejumlah harta tertentu yang diwajibkan Allah SWT diserahkan kepada orang-orang yang berhak (Soemitra, 2010).

\section{Dasar Hukum Zakat}

Zakat sebagai rukun Islam yang ketiga sebagai ibadah dan ketundukan kepada Allah SWT, juga memiliki fungsi sosial yang sangat besar, dan merupakan salah satu pilar ekonomi Islam. Jika zakat, infaq dan shadaqah ditata dengan baik, baik penerimaan dan pengambilannya maupun pendistribusiannya, Insya Allah akan mampu mengentaskan masalah 
kemiskinan atau paling tidak mengurangi masalah kemiskinan. Perintah zakat dalam Al-qur'an diantaranya :

"Dan dirikanlah shalat dan tunaikanlah zakat. dan kebaikan apa saja yang kamu usahakan bagi dirimu, tentu kamu akan mendapat pahala nya pada sisi Allah. Sesungguhnya Alah Maha melihat apa-apa yang kamu kerjakan." (QS.Al-Baqarah Ayat 110)

Dalil dari As-Sunnah atau Hadits adalah sabda Nabi Shalallahu Alaihi Wassalam dalam sebuah haditsnya :

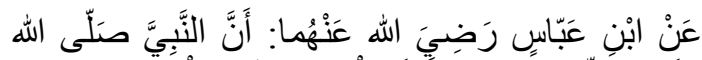

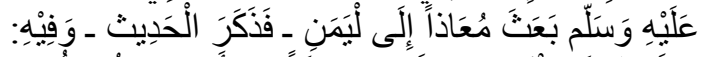

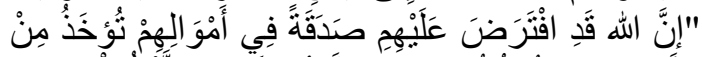

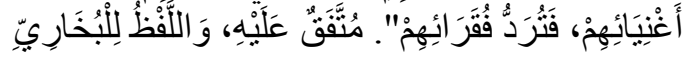

"Dari Ibnu Abbas ra. Bahwasanya Nabi saw. pernah mengutus Muadz ke Yaman, Ibnu Abbas menyebutkan hadits itu, dan dalam hadits itu Beliau bersabda : Sesungguhnya Allah telah memfardhukan atas mereka sedekah (zakat) harta mereka yang di ambil dari orang-orang kaya di antara mereka dan dikembalikan kepada orang-orang fakir di antara mereka" (HR Bukhary dan Muslim)

\section{Syarat Wajib Zakat}

1. Islam, maka tidak wajib zakat atas orang kafir asli (kafir asli adalah orang yang terlahir sebagai orang kafir karena kedua orang tuanya kafir dan tidak pernah masuk Islam).

2. Merdeka, maka zakat tidak wajib atas seorang budak.

3. Milik sempurna, maksudnya adalah dimiliki secara penuh. Zakat wajib di dalam harta yang dikuasai.

4. Nishab dan haul. Jika seseorang memiliki suatu harta, namun belum mencapai jumlah nishab atau belum sampai satu tahun (12 bulan), maka tidak ada zakatnya.

5. Berpikiran sehat dan dewasa (aqil dan baligh). Karena itu orang yang tidak dewasa, tidak mempunyai tanggung jawab. (Ra'ana, 1990).

\section{Jenis-Jenis Zakat}

\section{Zakat Fitrah}

Zakat Fitrah adalah zakat yang wajib dikeluarkan oleh setiap orang Muslim pria atau wanita, anak-anak atau dewasa, merdeka atau hamba. Kadar zakat fitrah yang dikeluarkan adalah 1 gantang, atau kira-kira 3,1/2 liter atau $2,5 \mathrm{~kg}$. Sedangkan makanan yang wajib dikeluarkan yang disebut nash hadits yaitu tepung, terigu, kurma, gandum, zahib (anggur) dan aqith (semacam keju). Waktu pembayaran zakat fitrah Imam Syafi' mengatakan bahwa pembayarannya dapat dilaksanakan sejak mulai masuknya bulan puasa, sedangkan imam-imam yang lainnya memberikan batasan waktunya. Pengikut Imam Hambali mengatakan paling cepat adalah 2 minggu sebelum hari raya 'Ied, sedangkan pengikut Imam Maliki memperpendeknya menjadi 3 hari sebelum hari raya 'Ied. (Al Kaaf, 2002)

\section{Zakat Maal atau Zakat Harta}

Jenis harta yang wajib di zakatkan dalam zakat maal dibedakan atas objek zakatnya antara lain:

1. Hewan ternak, seperti sapi, kerbau, kambing, domba.

2. Hasil pertanian. Hasil pertanian yang menjadi makanan pokok dan bisa bertahan.

3. Emas dan Perak.

4. Harta perniagaan. Harta perniagaan adalah semua yang diperuntukkan untuk diperjualbelikan.

5. Hasil tambang (Ma'din). 
6. Barang temuan (Rikaz). Yakni harta ditemukan dan tidak diketahui pemiliknya (harta karun).

7. Zakat profesi. Yakni zakat yang dikeluarkan dari hasil penghasilan profesi (hasil profesi). (Hertina, 2013)

Orang yang berhak menerima Zakat (Mustahik)

Pendistribusian zakat kepada asnap yang delapan sebagaimana dijelaskan dalam Al-Qur'an surat atTaubah : 60, yaitu: fakir, miskin, amil, mu'allaf, riqab (budak), gharimin (orang yang berhutang), fisabilillah, dan Ibnu Sabil. (Qardhawi, 2007)

\section{Lembaga Pengelola Zakat}

\section{Badan Amil Zakat Nasional (BAZNAS)}

BAZNAS merupakan lembaga yang berwenang melakukan tugas secara nasional. Dalam melaksanakan tugasnya BAZNAS yang merupakan lembaga yang berwenang dalam pengelolaan zakat, pastinya mempunyai tugas-tugas pokok dalam menyelenggarakan fungsinya, yaitu: merencanakan, melaksanakan, mengendalikan dan melaporkan, pengumpulan, pendistribusian, dan pendayagunaan zakat. (UU Pengelolaan Zakat No. 23 tahun 2011, pasal 6). Posisi pengelolaan dan pemberdayaan zakat ini semakin kuat di Negeri ini dengan keluarnya Keputusan Presiden RI Nomor 8 Tahun 2001 tentang pembentukan badan Amil Zakat Nasional (BAZNAS), dengan tugas-tugas pokoknya mencakup antara lain :

a. Meningkatkan kesadaran umat untuk berzakat. b. Mengarahkan masyarakat mencapai kesejahteraan baik fisik maupun non fisik melalui pendayagunaan zakat.

c. Meningkatkan status mustahik menjadi muzakki melalui pemulihan, peningkatan kualitas SDM, dan pengembangan ekonomi masyarakat.

d. Mengembangkan budaya "memberi lebih baik dari menerima" dikalangan mustahik.

e. Mengembangkan manajemen yang amanah, profesional dan transparan dalam mengelola zakat.

f. Menjangkau muzakki dan mustahik seluas-luasnya.

g. Memperkuat jaringan antar organisasi pengelola zakat. (Mujahidin, 2007)

\section{Lembaga Amil Zakat (LAZ)}

Lembaga Amil Zakat adalah organisasi yang dibentuk oleh masyarakat/swasta untuk kemaslahatan umat yang dibina dan di lindungi oleh negara/pemerintah, yang membantu BAZNAS dalam mengumpulkan, mendistribusikan, mendayagunakan zakat.

Pemberdayaan Ekonomi Masyarakat Melalui Zakat

Zakat merupakan konsep ajaran Islam yang mengandung nilai perbaikan ekonomi umat dalam memerangi kemiskinan. Sistem keuangan Islam telah mengatur bagaimana cara menunaikan zakat dalam merealisasikan dan penyempurnaan harta pada baitul maal untuk kemudian diberikan kepada delapan golongan penerima zakat. Tidak diragukan lagi, perolehan zakat sejak masa pemerintahan Islam sangatlah penting untuk memberdayakan fakir miskin, amil, muallaf, riqab, gharim, $f i$ 
sabilillah dan ibnu sabil. Para penerima zakat ini tentu membutuhkan dana yang besar untuk memenuhi kebutuhan yang mendesak, sebagai modal untuk mengembangkan harta sehingga mereka mempunyai penghasilan, mereka adalah penerima zakat dalam bentuk yang paling luas yang tetap sampai hari kiamat. (Inayah, 2003)

Zakat merupakan konsep ajaran Islam yang mengandung nilai perbaikan ekonomi umat dalam memerangi kemiskinan. Sebagai ajaran agama yang mengandung dimensi perbaikan ekonomi.

Pemberdayaan ekonomi masyarakat harus melibatkan tokohtokoh pemimpin umat atau pemerintah agar memerankan peran strategisnya. Karena, pemimpin umat merupakan agen pembaru yang paling dekat dengan kehidupan mereka sehingga sentuhan pola pikir dapat mengubah prilaku berproduksi, berdistribusi dan berkonsumsi. Jadi, untuk pemberdayaan ekonomi umat melalui zakat bahwa dengan membagikan zakat kepada mereka yang berhak dan harus melibatkan tokoh pemimpin atau pemerintah untuk meningkatkan kualitas kehidupan penerima zakat sehingga mampu hidup mandiri dalam memperbaiki ekonomi umat dalam memerangi kemiskinan.

\section{METODE PENELITIAN}

Penelitian ini dilakukan pada BAZNAS Kabupaten Kuantan Singingi Provinsi Riau yang beralamat di Jl. Jendral Sudirman No 98, Teluk Kuantan Kabupaten Kuantan Singingi. Yang menjadi subjek penelitian ini adalah Muzakki yang ada di Kabupaten Kuantan Singingi atau masyarakat selain Pegawai Negeri Sipil (PNS) yang berada di Kabupaten Kuantan Singingi. Sedangkan Objek dalam penelitian ini adalah faktor-faktor penyebab keengganan masyarakat dalam membayar zakat melalui BAZNAS Kabupaten Kuantan Singingi. Populasi dalam penelitian ini berjumlah 324.158 orang Islam yang ada di Kabupaten Kuantan Singingi, karena populasinya sangat luas maka teknik pengambilan sampel yang digunakan dalam penelitian ini adalah dengan cara teknik purposive sampling yaitu pengambilan sampel berdasarkan keperluan penelitian. Pengambilan subjek penelitian dilakukan sengaja dengan maksud dan tujuan tertentu berjumlah 65 orang responden karena dari 65 responden tersebut menurut peneliti sudah mewakili atau telah menyampaikan informasi yang dimaksud atau informasi yang valid.

Teknik Pengumpulan Data dalam penelitian ini dengan menggunakan teknik wawancara (interview) yaitu bertanya secara langsung kepada para pengelola BAZNAS Kabupaten Kuantan Singingi dan masyarakat yang tidak membayar zakat melalui BAZNAS dan observasi yaitu pengumpulan data yang peneliti lakukan dengan cara mengamati secara langsung di lapangan untuk mendapatkan gambaran secara nyata tentang kegiatan yang diteliti. Sedangkan teknik analisa yang digunakan dalam penelitian ini yaitu deskriptif Kualitatif.

HASIL DAN PEMBAHASAN

Sistem Pengumpulan Zakat oleh BAZNAS Kabupaten Kuantan Singingi

Sistem pengumpulan zakat oleh BAZNAS Kabupaten Kuantan Singingi ada 2 (dua) macam yaitu:

1. Sistem Jemput

$$
\text { Disini pihak BAZNAS }
$$

Kabupaten Kuantan Singingi mendatangi rumah muzakki yang akan membayar zakat, bagi para muzakki yang tidak bisa datang ke kantor BAZNAS kemudian meminta pihak BAZNAS untuk menjemput zakatnya 
maka pihak BAZNAS akan menjemput zakat muzakki sesuai dengan permintaan tersebut. Jadi tidak hanya menunggu muzakki yang datang untuk membayar zakatnya tetapi juga menjemput atau mengambil dana zakat tersebut kerumah muzakki.

2. Disetor melalui bidang pengumpulan atau melalui rekening BAZNAS Kabupaten Kuantan Singingi.

Muzakki dapat datang langsung ke BAZNAS Kabupaten Kuantan Singingi untuk membayarkan zakatnya melalui bidang pengumpulan zakat dan muzakki bisa juga menyetor zakatnya melalui rekening zakat yang telah ditentukan oleh BAZNAS Kabupaten Kuantan Singingi yaitu Bank Riau-Kepri Syariah No. $114 \quad 1104340$. Penggunaan rekening zakat adalah bagi muzakki yang ingin membayar zakatnya tapi tidak sempat atau mempunyai waktu luang untuk datang ke BAZNAS, maka muzakki dapat langsung datang ke bank yang telah ditunjuk oleh BAZNAS Kabupaten Kuantan Singingi yang ada diwilayah tempat tinggal muzakki untuk memudahkan muzakki mengirim zakatnya melalui rekening atas nama BAZNAS Kabupaten Kuantan Singingi Riau.

\section{Untuk}

memperlancar pengumpulan dana zakat, BAZNAS Kabupaten Kuantan Singingi melakukan kerja sama dengan instansi pemerintah maupun swasta yaitu dengan cara membentuk Unit Pelayanan Zakat (UPZ) jadi bagi instansi pemerintah dan swasta cara pengumpulan zakatnya melalui bendahara masing-masing UPZ instansi tersebut, kemudian bendahara UPZ instansi tersebut yang membayarkan atau menyetor dana zakat yang sudah terkumpul tersebut ke BAZNAS Kabupaten Kuantan Singingi.

Badan Amil Zakat Nasional (BAZNAS) Kabupaten Kuantan Singingi dalam operasinya telah mengumpulkan uang sebanyak Rp. 24.955.531.209 (Dua puluh empat milyar sembilan ratus lima puluh lima juta lima ratus tiga puluh satu ribu dua ratus sembilan rupiah) mulai tahun 2014 s.d 2015 sebagaimana terlihat pada tabel berikut ini :

\section{Tabel 1. Penerimaan Dana Zakat oleh BAZNAS Kabupaten Kuantan Singingi}

Tahun 2014-2016

\begin{tabular}{ccc}
\hline No & Tahun & Penerimaan \\
\hline 1 & 2014 & 7.523 .102 .232 \\
\hline 2 & 2015 & 8.672 .566 .608 \\
\hline 3 & 2016 & 8.759 .862 .369 \\
\hline & Total & 24.955 .531 .209 \\
\hline
\end{tabular}

$\overline{\text { Sumber : Laporan Keuangan BAZNAS Kabupaten Kuantan Singing }}$ i 
Berdasarkan tabel 1 diatas, pada tahun 2014 total dana zakat BAZNAS Kabupaten Kuantan Singingi berjumlah Rp. 7.523.102.232,- sedangkan dana zakat yang terkumpul pada tahun 2015 sebanyak Rp. 8.672.566.608,- kemudian pada tahun 2016 total dana zakat BAZNAS Kabupaten Kuantan Singingi berjumlah Rp.8.759.862.369,--

Faktor-faktor yang menyebabkan Keengganan Masyarakat (Non PNS) membayar zakat melalui BAZNAS Kabupaten Kuantan Singingi

Penerimaan zakat di Badan Amil Zakat Nasional (BAZNAS) Kabupaten
Kuantan Singingi yang paling banyak adalah zakat profesi dari UPZ Dinas Instansi pemerintah dan swasta jika dibandingkan dengan penerimaan zakat perseorangan ataupun melalui Badan Amil Zakat Kecamatan (BAZ Kec.) dari masyarakat yang berada di Kabupaten Kuantan Singingi ini ataupun muzakki yang diluar Pegawai Negeri Sipil (PNS). Dan untuk lebih jelas jumlah muzakki yang membayar zakat melalui BAZ kecamatan dan perseorangan kepada BAZNAS Kabupaten Kuantan Singingi dapat dilihat pada tabel berikut ini :

Tabel 2. Jumlah Muzakki yang membayar zakat Perseorangan (Non PNS)

\begin{tabular}{ccc} 
No & Tahun & $\begin{array}{c}\text { Jumlah Muzakki } \\
\text { Perseorangan }\end{array}$ \\
\hline $\mathbf{1}$ & $\mathbf{2 0 1 5}$ & $\mathbf{9 4}$ \\
\hline $\mathbf{2}$ & $\mathbf{2 0 1 6}$ & $\mathbf{6 7}$ \\
\hline \multicolumn{3}{c}{ Total } \\
\hline \multicolumn{2}{c}{ Sumber : Laporan Keuangan BAZNAS Kabupaten Kuantan Singingi }
\end{tabular}

Berdasarkan tabel 2 di atas, dapat dilihat bahwa jumlah muzakki yang membayar zakat perseorangan melalui BAZNAS pada tahun 2015 jumlah muzakki sebanyak 94 orang, sedangkan pada tahun 2016 sebanyak 67 orang. Jadi dapat disimpulkan bahwa dari tahun 2015 sampai 2016 mengalami penurunan jumlah muzakki yang membayar zakat kepada BAZNAS Kabupaten Kuantan Singingi. Dari temuan peneliti dilapangan bahwa ada beberapa hal penyebab masyarakat (Non PNS) tidak mau atau enggan membayar zakatnya kepada BAZNAS Kabupaten Kuantan Singingi yaitu sebagai berikut:

1. Religiusitas (masyarakat merasa lebih afdhal memberikan zakat langsung kepada mustahiq yang masih merupakan saudara atau warga yang berada disekitar tempat tinggalnya)
Muzakki merasa lebih afdhal dan praktis membayar zakatnya sendiri, kemudian mereka bisa memilih siapa saja mustahiq yang akan mereka berikan zakatnya. Seperti yang yang dikatakan oleh ibu Kasmina bahwa lebih afdhal membayar zakat sendiri dari pada ke BAZNAS, kita lebih tahu masyarakat yang kurang mampu di Desa dan bisa memberi lebih leluasa secara lansung kepada orang-orang terdekat. (Kasmina, Muzakki, Wawancara, Logas 06 April 2017). Begitu juga Ibu Yuli Yanti mengatakan bahwa mengeluarkan/membayar zakat sendiri dan lebih suka membayar zakatnya kepada anak yatim yang berada disekitarnya. (Yuli Yanti, 
Muzakki, Wawancara, Sukaraja 18 April 2017)

Muzakki sudah terbiasa dalam membayar zakat ke masjid tempat mereka tinggal dan mustahiq yang menerima juga sudah jelas orangnya yaitu orang yang mereka ketahui atau dikenali yaitu masyarakat yang berada ditempat tinggal mereka dari sana ada rasa kepuasaan tersendiri ketika bisa membantu warga tempat tinggal mereka. Seperti Yonavia warga Jl. Sisingamangaraja Teluk Kuantan ini mengatakan bahwa dia sudah terbiasa untuk membayar zakatnya di Masjid. (Yonavia, Muzakki, Wawancara, Teluk Kuantan 06 April 2017) Selain itu karena adanya faktor kebanggaan dari muzakki ketika membayar zatnya sendiri. Seperti yang dikatakan oleh bapak Marjono warga muara sentajo dia mengatakan bahwa membayar zakat ke Masjid dia merasakan kebanggaan tersendiri. (Marjono, Muzakki, Wawancara, Logas 10April 2017)

Jadi, dapat disimpulkan bahwa masyarakat lebih suka membayar zakatnya sendiri dan ada juga yang langsung membayar zakat ke Masjid ditempat mereka tinggal kebanyakannya masyarakat beralasan lebih mudah dan lebih afdhal ketika membayar zakat sendiri dan ketika zakat disalurkan kepada mustahiq mereka mengetahui siapa saja mustahiq yang mendapatkan zakat yang telah mereka bayar kemudian mereka bisa memilih siapa mustahiq yang pantas mendapatkan zakat dari muzakki tersebut.
2. Kepercayaan

(Kurangnya kepercayaan masyarakat terhadap BAZNAS dalam menyalurkan zakat kepada mustahiq)

$$
\text { Kurangnya }
$$

tingkat

kepercayaan masyarakat atau muzakki untuk membayar zakat ke BAZNAS dalam hal ini ada muzakki yang takut uang zakat tersebut diselewengkan dan takut dananya tersebut tidak disalurkan kepada masyarakat. Ada juga yang mengatakan tidak percaya pihak lain (BAZNAS) (Bambang Widodod, Muzakki, Wawancara, Teluk Kuantan 12 April 2017). Kemudian muzakki ada yang mengatakan agar zakatnya tepat sasaran dan tidak disalah gunakan, (Hendry Karno, Muzakki, Wawancara, Teluk Kuantan 12 April 201). Hal tersebut juga diungkapkan oleh Ibu Subahanna warga Desa Air Emas Kecamatan Singingi bahwa dia mengatakan tidak membayar zakat ke BAZNAS karena ketidakpercayaan apabila membayar zakatnya ke BAZNAS. (Subahanna, Muzakki, Wawancara, Air Emas Kecamatan Singingi, 17 April 2017)

3. Belum tau keberadaan BAZNAS dan juga karena muzakki belum tau prosedur pembayaran zakat melalui BAZNAS.

\begin{tabular}{lrr}
\multicolumn{2}{c}{ Karena muzakki belum } \\
mengerti bahkan ada yang \\
mengatakan belum tau tentang
\end{tabular}
BAZNAS. Seperti yang dikatakan oleh Muhasdi warga Perhentian Luas, Pangean mengatakan bahwa dia belum mengerti cara membayar zakat ke BAZNAS. Dan Jeni warga Desa Sako, Kecamatan Logas Tanah Darat 
bahwa dia belum mengetahui adanya BAZNAS dan dia juga beralasan karena di Desanya juga sudah ada panitia zakat yang bertanggung jawab. (Jeni, Muzakki, Wawancara, Kuantan Sako 21 April 2017)

4. Lokasi (Lokasi/jarak BAZNAS yang cukup jauh dari tempat tinggal)

Jarak yang jauh juga menjadi kendala oleh muzakki untuk membayar zakatnya kepada BAZNAS Kabupaten Kuantan Singingi ini, sehingga muzakki akhirnya membayar zakatnya di Mesjid tempat tinggal mereka. Seperti yang dikatakan oleh Ibu Karmini bahwa jarak yang susah ditempuh yang membuatnya tidak ingin berzakat ke BAZNAS. Sama seperti yang diungkapkan oleh bapak Suto Dirjo warga Desa Sukaraja bahwa tidak pernah membayar zakat ke BAZNAS karena terlalu jauh dan lebih memilih membayar zakat di Mesjid saja. (Suto Dirjo, Muzakki, Wawancara, Kuantan Sako 21April 2017)

Dapat disimpulkan bahwa faktor-faktor keengganan masyarakat (Non PNS) untuk membayar zakat kepada BAZNAS Kabupaten Kuantan Singingi adalah sebagai berikut : pertama karna Religiusitas (Masyarakat merasa lebih afdhal memberikan zakat langsung kepada mustahiq yang masih merupakan saudara), kemudian karena kurangnya tingkat kepercayaan muzakki kepada BAZNAS dan juga karena muzakki tidak tau keberadaan BAZNAS dan tidak tahu prosedur membayar zakat di BAZNAS tersebut, dan terakhir karena alasan jarak tempuh yang jauh dari rumah muzakki ke BAZNAS.

Hal ini juga diakui oleh bapak Syahrial beliau mengatakan bahwa hal yang menjadi penyebab keengganan masyarakat (Non PNS) membayar zakat kepada BAZNAS Kabupaten Kuantan Singingi itu yang pertama karena Tingkat Kepercayaan masyarakat itu sendiri kurang kepada pihak BAZNAS dan yang kedua karena Faktor Kebanggaan dari masyarakat itu sendiri sehingga dia ingin membayar zakatnya secara lansung kepada mustahiq. (Syahrial, Wakil Ketua II (Bidang Pendistribusian dan Pendayagunaan) BAZNAS Kabupaten Kuantan Singingi, Wawancara, Teluk Kuantan 15 Maret 2017)

Dari hasil wawancara diatas bisa kita lihat bahwa pihak BAZNAS sendiri juga mengakui adanya faktorfaktor yang menyebabkan keengganan masyarakat untuk membayarkan zakatnya di BAZNAS, hanya saja disini dikatakan bahwa hal utama yang menjadi penyebab masyarakat enggan atau tidak mau membayar zakat kepada BAZNAS karena kurangnya tingkat kepercayaan masyarakat atau muzakki untuk membayarkan zakatnya melalui BAZNAS itu sendiri kemudian disusul oleh faktor dari diri masyarakat atau muzakki tersebut yang mana mereka merasa ada kepuasan tersendiri ketika mereka sendiri yang membayarkan lansung zakatnya kepada mustahiq. 
Kebijakan yang ditempuh oleh BAZNAS Kabupaten Kuantan Singingi dalam Menarik masyarakat (Non PNS) untuk membayar zakatnya melalui BAZNAS

Penerimaan zakat di BAZNAS Kabupaten Kuantan Singingi sampai saat ini masih memang di dominasi oleh penerimaan zakat dari instansi pemerintah dan swasta sedangkan dari masyarakat (Non PNS) bisa dikatakan masih sedikit sekali penerimaan zakatnya atau pembayaran zakatnya melalui BAZNAS Kabupaten Kuantan Singingi padahal sama-sama kita ketahui bahwa penduduk Kabupaten Sigingi ini mayoritas beragama Islam. Dengan demikian maka BAZNAS Kabupaten Kuantan Singingi harus memiliki upaya bagaimana cara menarik masyarakat agar mau membayarkan zakatnya melalui BAZNAS.

Kebijakan yang dilakukan oleh BAZNAS Kabupaten Kuantan Singingi dalam menarik masyarakat dalam membayar zakat melalui BAZNAS dengan cara :

1. Sosialisasi

$$
\text { Hal utama dalam }
$$

pengumpulan zakat oleh BAZNAS kuansing ini adalah mensosialisasikan pembayaran zakat oleh muzakki melalui BAZNAS. Sebagian besar masyarakat sudah mengetahui pentingnya membayar zakat namun kesadaran untuk membayarkannya sedikit sekali. Untuk mengatasi hal tersebut, BAZNAS Kabupaten Kuantan Singingi mengadakan sosialisasi kepada masyarakat untuk menumbuhkan kesadaran berzakat. Sosialisasi tersebut melalui brosur, buku panduan berzakat, pengajianpengajia, memasang iklan baik di media cetak maupun media elektronik.

2. Ceramah tentang Zakat.

$\begin{array}{ll}\text { Ceramah tentang } & \text { wajibnya } \\ \text { membayar zakat sekaligus }\end{array}$
memberitahukan kepada masyarakat tentang pembayaran zakat melalui BAZNAS Kabupaten Kuantan Singingi, ceramahnya dilakukan dilakukan misalnya dalam acara-acara pengajian, khutbah jum'at dll.

3. Motivasi dan pemahaman

Motivasi disini adalah bagaimana caranya agar masyarakat atau muzakki benar-benar tergugah hatinya untuk membayar zakat melalui BAZNAS Kabupaten Kuantan Singingi itu sendiri sekaligus memberikan pemahaman kepada masyarakat bagaimana prosedur pembayaran zakat tersebut melalui BAZNAS Kabupaten Kuantan Singingi. Motivasi dan memberikan pemahaman tentang zakat ini kepada muzakki dilakukan oleh pihak BAZNAS baik kepada muzakki yang datang ke kantor BAZNAS juga kepada muzakki yang ketika melakukan sosialisasi dan juga pada saat ceramah tentang zakat kepada masyarakat yang berada di Kabupaten Kuantan Singingi ini.

4. Transparansi Pendistribusian

Hal yang tidak kalah penting disini adalah masalah transparansi pendistribusian zakat itu sendiri, supaya muzakki atau masyarakat yang telah membayar zakat melalui BAZNAS tersebut merasa lega bahwa zakatnya sudah sampai ketangan mustahiq zakat itu sendiri. Dan tranparansi pendistribusian zakat juga 
akan sangat berpengaruh terhadap tingkat kepercayaan masyarakat itu sendiri kepada BAZNAS dan supaya masyarakat tersebut merasa atau bisa meningkatkan kepercayaannya kepada pihak BAZNAS sehingga akan mempengaruhi jumlah muzakki yang membayar zakat kepada BAZNAS.

5. Merancang Perda Zakat

Perda zakat juga sangat diperlukan agar bisa menarik minat masyarakat untuk membayar zakat itu melalui BAZNAS Kabupaten Kuantan Singingi, karena dalam hal ini zakat tidak hanya menjadi kewajiban kita sebagai umat Islam tetapi sekarang dalam pengelolaan zakat juga sudah dikelola oleh pemerintah, penerimaannya, pendistribusian dan juga pengelolaan zakat itu sendiri. Tapi perda zakat itu sendiri masih dalam wacana belum terlealisasikan tetapi sebelumnya juga pernah ada surat perihal penunaian zakat melalui BAZNAS kepada dinas Instansi pemerintah dan swasta pada masa bupati Sukarmis yang mana surat pemberitahuan tersebut dikeluarkan di Teluk Kuantan, tanggal 10 Oktober tahun 2011 tetapi hanya ditujukan kepada Dinas Instansi pemerintah dan Swasta saja bukan kepada masyarakat luas (Non PNS).

\section{KESIMPULAN}

1. Sistem pengumpulan zakat oleh BAZNAS Kabupaten Kuantan Singingi dua sistem yaitu Pertama sistem jemput yaitu zakat tersebut lansung di jemput oleh pihak
BAZNAS kepada muzakki dan Kedua disetor yaitu muzakki bisa menyetor lansung zakatnya melalui BAZNAS Kabupaten Kuantan Singingi.

2. Faktor-faktor yang menyebabkan keengganan masyarakat untuk membayar zakat melalui BAZNAS tersebut yang pertama adalah Religiusitas (Masyarakat merasa lebih afdhal memberikan zakat langsung kepada mustahiq) karena tingkat kepercayaan masyarakat tersebut rendah kepada BAZNAS dan juga disebabkan muzakki kurang mengerti bagaimana prosedur ataupun cara pembayaran zakat kepada BAZNAS Kabupaten Kuantan Singingi, dan terakhir karena muzakki atau masyarakat beralasan kantor BAZNAS jauh dari tempat tinggal mereka, sedangkan pembayaran zakat melalui BAZNAS Kabupaten Kuantan Singingi itu sendiri tidak mesti harus datang ke kantor BAZNAS tetapi juga bisa transfer zakatnya melalui rekening BAZNAS Kabupaten Kuantan Singingi.

3. Kebijakan yang dilakukan oleh BAZNAS Kabupaten Kuantan Singingi dalam menarik muzakki atau masyarakat untuk membayar zakatnya melalui BAZNAS dengan gencar mensosialisasikan keberadaan BAZNAS itu sendiri kepada masyarakat, dengan melakukan ceramah zakat dan juga memotivasi dan memberikan pemahaman kepada masyarakat untuk membayar zakat melalui BAZNAS. 


\section{SARAN}

1. Lembaga BAZNAS harus terus melakukan sosialisasi kepada masyarakat untuk meningkatkan pemahaman masyarakat terhadap fungsi BAZNAS, agar dapat meningkatkan kepercayaan masyarakat terhadap BAZNAS. Kemudian BAZNAS diharapkan memberikan kemudahan akses kepada masyarakat berupa lokasi yang mudah dijangkau, lebih mensosialisasikan pembayaran zakat bisa ditransfer melalui rekening BAZNAS dan BAZNAS memberikan manajemen dan informasi secara transparan, sehingga masyarakat tertarik menyalurkan zakatnya melalui BAZNAS.

2. Masyarakat Kabupaten Kuantan Singingi diharapkan dapat menggunakan jasa BAZNAS dalam menyalurkan/membayar zakatnya di BAZNAS Kabupaten Kuantan Singingi yang berada di Teluk Kuantan.

\section{DAFTAR PUSTAKA}

Al Kaaf, Abdullah Zaky. 2002. Ekonomi Dalam Perspektif Islam. Pustaka Setia. Bandung.

Departemen Agama RI. (1996). AlQur'an dan Terjemahnya. Toha Putra. Semarang.

Effendy, Mochtar, 1996. Ekonomi Islam Suatu Pendekatan Berdasarkan Ajaran Qur'an dan Hadis. AlMukhtar. Palembang.

Hafidhuddin, Didin. 2003. Islam Aplikatif. Gema Insani. Jakarta.

Halim, M Nipan Abdul. 2001. Mengapa Zakat Disyariatkan. : M2S. Bandung.

Hasan, Ali Muhammad. 2006. Zakat dan infaq: Salah Satu Solusi
Mengatasi Proplema Sosial di Indonesia. Kencana Prenada Media Group. Jakarta.

Hasan, M. Ali. 2003. Zakat, Pajak Asuransi dan Lembaga Keuangan (Masail Fiqhiyah II). Raja Grafindo Persada. Jakarta.

Hertina. 2013. Proplematika Zakat Profesi Dalam Produk Hukum di Indonesia. Suska Press. Pekanbaru.

Inayah, Ghazy. 2003. Teori Komprehensif Tentang zakat dan Pajak. Tiara Wacana. Yogyakarta. Mujahidin, Akhmad. 2007. Ekonomi Islam. RajaGrafindo Pers. Jakarta.

Mursyidi. 2003. Akuntansi Zakat Kontemporer. PT Remaja Rosdakarya. Bandung.

Qardhawi, Yusuf. 2007. Hukum Zakat. PT. Pustaka Litera Antar Nusa. Bogor.

Ra'ana, Irpan Mahmud. 1990. Sistem Ekonomi Pemerintahan Umar Ibn Al-Khatab. Pustaka Firdaus. Jakarta.

Soemitra, Andri. 2010. Bank dan Lembaga Keuangan Syari'ah. Kencana. Jakarta.

Undang-Undang Republik Indonesia No. 23 Tahun 2011 Tentang Pengelolaan Zakat. 